\title{
The Marine Biological Association
}

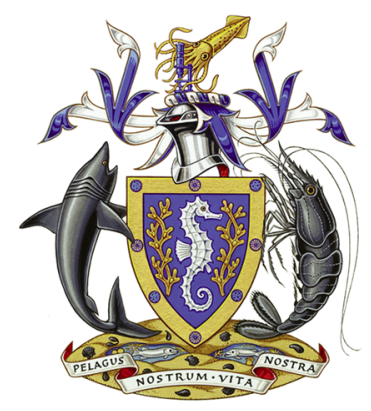

"The future now is in the hands of those who understand the real importance of the blue part of the planet"

Dr Sylvia Earle Hon.MBA

Join a global community promoting marine science excellence.

Professional Membership of the MBA provides:

o use of the post-nominal Mem.MBA

- The Marine Biologist magazine

o access to an Experts Database to connect with other professionals

o opportunities to influence marine policy

- a Certificate of Membership.

- an exclusive MBA pin badge

o access to research awards and grants And much more!

Fellow FMBA $£ 120^{*}$, Professional Mem.MBA $£ 45^{*}$, Associate $£ 40^{*}$, Student $£ 25$ ${ }_{£} 5$ Direct Debit discount

T: +44 (0) 1752426493 | E: membership@mba.ac.uk | www.mba.ac.uk @thembauk $\because$ f

\section{Providing an authoritative and} independent voice for the marine biological community.

\section{PUBLISHED BY THE PRESS SYNDICATE OF THE UNIVERSITY OF CAMBRIDGE}

The Pitt Building, Trumpington Street, Cambridge, CB2 1RP, United Kingdom

This journal issue has been printed on FSC-certified paper and cover board. FSC is an independent, non-governmental, not-for-profit organization established to promote the responsible management of the world's forests. Please see www.fsc.org for information.

Printed by Bell and Bain Limited, Glasgow

\section{CAMBRIDGE UNIVERSITY PRESS}

Journals Fulfillment Department, UPH, Shaftesbury Road, Cambridge CB2 8BS, United Kingdom

1 Liberty Plaza, Floor 20, New York, NY 10006, USA

477 Williamstown Road, Port Melbourne, VIC 3207, Australia

C/ Orense, 4, planta 13, 28020, Madrid, Spain

Dock House, The Waterfront, Cape Town 8001, South Africa 
JMBA

JOURNAL OF THE MARINE BIOLOGICAL ASSOCIATION OF THE UNITED KINGDOM

\section{VOLUME 101.6 SEPTEMBER 2021}

CONTENTS

REVIEW

Cunha, R. and Tavares, M. A review of the genus Narcissia Gray, 1840 (Echinodermata: Asteroidea: Ophidiasteridae)

RESEARCH ARTICLES

Castañeda-Quezada, R., Garcia-Mendoza, E., Ramírez-Mendoza, R., Helenes, J., Rivas, D., Romo-Curiel, A.E. and

Lago-Lestón, A. Distribution of Gymnodinium catenatum Graham cysts and its relation to harmful

algae blooms in the northern Gulf of California

Menezes, N.M., McFadden, C.S., Miranda, R.J., Nunes, J.A.C.C., Lolis, L., Barros, F., Sampaio, C.L.S. and Pinto, T.K.

New non-native ornamental octocorals threatening a South-west Atlantic reef

Kobayashi, G. and Sakamoto, T. New record of bioluminescence in Odontosyllis cf. australiensis

(Annelida: Syllidae: Eusyllinae) in Japan

Hookabe, N., Jimi, N., Yokooka, H., Tsuchida, S. and Fujiwara, Y. Lacydonia shohoensis

(Annelida, Lacydoniidae) sp. nov. - a new lacydonid species from deep-sea sunken wood discovered at the

Nishi-Shichito Ridge, North-western Pacific Ocean

Batista, B.B., Matthews-Cascon, H., Marinho, R.A., Kikuchi, E. and Haimovici, M. The growth and population dynamics of

Octopus insularis targeted by a pot longline fishery in north-eastern Brazil

Nakasugi, F., Shimanaga, M., Nomaki, H., Watanabe, H.K., Kitahashi, T., Motomura, Y. and Iseda, K.

Simple harpacticoid composition observed at deep hydrothermal vent sites on sea knoll calderas in the

North-west Pacific

Torjman, B.L. and lyengar, E.V. Increased potential for shell competition among hermit crabs

(Pagurus beringanus and Pagurus granosimanus) in the rocky intertidal

Ghosh, S., Hoshalli, M.M., Rohit, P., Mamidi, S., Eruppakkottil, M.A. and Achamveetil, G. Observations on the trophodynamics of sawtooth barracuda, Sphyraena putnamae from the Bay of Bengal, northern Indian Ocean 